$$
\begin{array}{r|l}
\text { Jurnal Sains Komputer dan Teknologi Informasi } & \text { Page } \\
\text { e-issn : 2655 7460. Volume 3 No.2, Mei 2021 } & 56-63
\end{array}
$$

\title{
ANALISIS DAN PENGUJIAN SISTEM MENGGUNAKAN BLACK BOX TESTING EQUIVALENCE PARTITIONING
}

(Studi Kasus : Sistem Informasi Inventarisasi Barang Berbabis Web Pada Madrasah Tsanawiyah Negeri 2 Palangka Raya)

\author{
Rosmiati \\ Sistem Informasi - STMIK Palangkaraya \\ Jl. G. Obos No. I I 4 Palangkaraya Kalimantan Tengah \\ Email : fayadhah@gmail.com
}

\begin{abstract}
ABSTRAK
Pengembangan sebuah sistem informasi haruslah melakukan tahapan pengujian sistem khususnya unitunit sistem tersebut. Pengujian ini dilakukan dengan tujuan sebelum sistem diterapkan pada pemakai akhir sistem tersebut, sistem telah sesuai dengan prosedur pengembangan dan telah sesuai dengan fungsi dari unit-unit sistem tersebut. Pada Sistem Informasi Inventarisasi Barang Berbasis Web Pada Madrasah Tsanawiyah Negeri 2 Palangka Raya sebelumnya telah dilakukan pengujian sistem menggunakan menggunakan metode black-box dengan fokus pada sebagian pengujian input dan pengujian proses. Namun proses pengujian input tersebut belumlah secara maksimal dilakukan, karena pengujian dilakukan hanya pada kasus proses input tertentu dan tidak secara keseluruhan sistem. Oleh karena itulah maka diperlukan prosedur pengujian ulang yang secara struktur dan menyeluruh untuk memastikan bahwa perangkat lunak atau sistem yang dikembangkan sebelumnya telah layak lulus uji sehingga sistem tersebut layak untuk digunakan pada pemakai akhir sistem dengan menggunakan metode Black Box Testing Equivalence Partitioning. Dari pengujian yang dilakukan menghasilkan masih terdapat kesalahan-kesalahan algoritma dalam proses input data sehingga perlu dilakukan proses rekayasa perangkat lunak ulang.

Kata kunci : Ujicoba sistem, Sistem informasi, Black Box Testing Equivalence Partitioning
\end{abstract}

\section{ABSTRACT}

The development of an information system must carry out the system testing stages, especially the system units. This test is carried out with the aim before the system is applied to the end user of the system, the system is in accordance with the development procedure and is in accordance with the functions of the system units. In the Web-Based Goods Inventory Information System at Madrasah Tsanawiyah Negeri 2 Palangka Raya, system testing has previously been carried out using the black-box method with a focus on partial input testing and process testing. However, the input testing process has not been maximally carried out, because testing is carried out only in the case of certain input processes and not as a whole system. Therefore, a structural and comprehensive retesting procedure is needed to ensure that the previously developed software or system is feasible to pass the test so that the system is suitable for use by end users of the system by using the Black Box Testing Equivalence Partitioning method. From the tests carried out, there are still algorithmic errors in the data input process so it is necessary to re-engineer the software.

Keywords : System test, Information Systems, Black Box Testing Equivalence Partitioning

\section{PENDAHULUAN}

Dalam pembuatan ataupun pengembangan sebuah sistem informasi haruslah melakukan tahapan pengujian sistem khususnya unit-unit sistem tersebut. Pengujian ini dilakukan dengan tujuan sebelum sistem diterapkan pada pemakai akhir sistem tersebut, sistem telah sesuai dengan prosedur pengembangan dan telah sesuai dengan fungsi dari unit-unit sistem tersebut.

Penelitian Rahman (2016) dengan judul Sistem Informasi Inventarisasi Barang Berbasis Web Pada Madrasah Tsanawiyah Negeri 2
Palangka Raya, dalam melakukan pengujian sistem yang digunakan menggunakan metode black-box dengan fokus pada sebagian pengujian input dan pengujian proses.

Namun proses pengujian input tersebut belumlah secara maksimal dilakukan, karena pengujian dilakukan hanya pada kasus proses input tertentu dan tidak secara keseluruhan sistem. Hal ini dapat berakitbat tidak sempurnanya sebuah perangkat lunak yang dikembangkan atau tidak dapat diyakinkan apakah 
perangkat lunak atau sistem yang dikembangkan tersebut telah lulus uji atau tidak.

Berdasarkan pemaparan sebelumnya maka diperlukan prosedur pengujian ulang yang secara struktur dan menyeluruh untuk memastikan bahwa perangkat lunak atau sistem yang dikembangkan sebelumnya telah layak lulus uji sehingga sistem tersebut layak untuk digunakan pada pemakai akhir sistem dalam hal ini pada Madrasah Tsanawiyah Negeri 2 Palangka Raya.

\section{Landasan Teori}

\section{I. Analisis}

Menurut Kamus Besar Bahasa Indonesia (2018), analisis adalah Penyelidikan terhadap suatu peristiwa (karangan, perbuatan, dan sebagainya) untuk mengetahui keadaan yang sebenarnya (sebab-musabab, duduk perkaranya, dan sebagainya) ; Penjabaran sesudah dikaji sebaik-baiknya; Pemecahan persoalan yang dimulai dengan dugaan akan kebenarannya.

\subsection{Pengujian Sistem}

Pengujian atau testing merupakan elemen kritis dari jaminan kualitas perangkat lunak dan merupakan bagian yang tidak terpisah dari siklus hidup pengembangan software seperti halnya analisis, desain, dan pengkodean. (Shi, 20l0).

\subsection{Black-Box Testing}

Menurut Nugroho (2010:301) Black-Box merupakan pengujian mengenai apa yang dilakukan oleh sistem terutama perilaku dan masalah- masalahnya. Black-box dilakukan untuk mengidentipikasi Bug yang terdapat pada hasilhasil, pemprosesan dan perilaku dari sistem. Black-Box biasanaya dilakukan oleh tester. Tester dapat mengidentifikasi kumpulan kondisi Input dan melakukan pengetesan pada spesifikasi fungsional program.

\subsection{Equivalence Partitioning}

Equivalence Partitioning adalah metode pengujian black-box yang memecah atau membagi domain input dari program ke dalam kelas-kelas data sehingga test case dapat diperoleh. Perancangan test case equivalence partitioning berdasarkan evaluasi kelas equivalence untuk kondisi input yang menggambarkan kumpulan keadaan yang valid atau tidak. Kondisi input dapat berupa nilai numeric, range nilai,kumpulan nilai yang berhubungan atau kondisi Boolean.

\begin{tabular}{rllll} 
USERNAME & & & \\
invalid & 10 & valid & 15 & invalid \\
\hline PASSWORD & & & & \\
invalid & 8 & valid & 16 & invalid \\
\hline
\end{tabular}

Gambar I. Contoh Equivalence Partitioning

\section{JENIS PENELITIAN}

Jenis penelitian yang dilakukan dalam penelitian yaitu penelitian terapan (applied research) berdasarkan penggunaannya dan penelitian deskripstif berdasarkan tingkat eksplanasi (penjelasannya). Dikatakan penelitian terapan (applied research) sebab hasil penelitian yang dilakukan untuk menghasilkan solusi dari permasalahan yang diangkat, serta dikatakan penelitian deskriptif sebab hasil dari penelitian ini yaitu kesimpulan deskriptif penelitia terhadap hasil penelitian yang diharapkan mampu menjadi solusi pemecahan masalah.

\section{ANALISIS DAN DESAIN}

\section{I. Analisis Rancangan Basis Data}

Pada struktur tabel tanah terdapat beberapa penggunaan tipe data yang kurang sesuai dengan fungsi input, misalnya field luastanah, luasbangun, luassarana, luaskosong digunakan tipe data varchar namun, pada praktiknya harusnya menggunakan tipe data int karena data yang diinput-kan adalah berupa angka atau numeric. Pada struktur tabel gedung, penggunaan tipe data yang kurang sesuai masih ditemukan pada beberapa field, misalnya luasbangunan, lantai seharusnya menggunakan tipe data int karena nilai input nya adalah numeric. Pada tabel kendaraan pemilihan tipe data lebih sesuai dengan nilai input yang diharapkan, hanya terdapat pemilihan panjang karakter pada beberapa field yang dirasa terjadi pemborosan. Pada tabel aset lainnya pemilihan tipe data juga masih ditemukan, misalnya untuk 
field bnyk_barang dan nilai_peroleh lebih tepat menggunakan tipe data int dikarenakan input yang diharapkan adalah berupa data numeric.

\subsection{Desain Butir Uji Pengujian Sistem}

Desain butir uji pengujian sistem merupakan rencana pengujian sustem yang ditentukan untuk mendapatkan nilai yang valid dan tidak valid berdasarkan nilai input yang diharapkan sesuai dengan tipe data yang terdapat pada basis data yang dapat dilihat pada tabel berikut.

Tabel I. Desain Butir Uji Input Data Tanah

\begin{tabular}{|c|c|c|c|}
\hline No & Test Uji & Valid Data & Invalid Data \\
\hline I & $\begin{array}{l}\text { Uji } \\
\text { Formulir } \\
\text { input data } \\
\text { tanah }\end{array}$ & $\begin{array}{l}\text { Formulir } \\
\text { input data } \\
\text { tanah diisi } \\
\text { secara } \\
\text { lengkap }\end{array}$ & $\begin{array}{l}\text { Formulir } \\
\text { input data } \\
\text { tanah } \\
\text { dikosongkan } \\
\text { atau diisi } \\
\text { sebagian }\end{array}$ \\
\hline 2 & $\begin{array}{l}\text { Uji kode } \\
\text { aset tanah }\end{array}$ & $\begin{array}{l}\text { Memilih } \\
\text { kode aset } \\
\text { berdasarkan } \\
\text { pilihan }\end{array}$ & $\begin{array}{l}\text { tidak memilih } \\
\text { kode aset }\end{array}$ \\
\hline 3 & $\begin{array}{l}\text { Uji nomor } \\
\text { urut aset } \\
\text { tanah }\end{array}$ & $\begin{array}{l}\text { Diisi } \\
\text { karakter } \\
\text { numerik dan } \\
\text { panjang } \\
\text { maksimal } 4\end{array}$ & $\begin{array}{l}\text { Diisi karakter } \\
\text { bukan } \\
\text { numerik atau } \\
\text { gabungan } \\
\text { karakter } \\
\text { numerik dan } \\
\text { bukan } \\
\text { numerik dan } \\
\text { jumlah } \\
\text { karakter lebih } \\
\text { dari } 4\end{array}$ \\
\hline 4 & $\begin{array}{l}\text { Uji luas } \\
\text { tanah }\end{array}$ & $\begin{array}{l}\text { Diisi } \\
\text { karakter } \\
\text { numerik }\end{array}$ & $\begin{array}{l}\text { Diisi karakter } \\
\text { bukan } \\
\text { numerik atau } \\
\text { gabungan } \\
\text { karakter } \\
\text { numerik dan } \\
\text { bukan } \\
\text { numerik }\end{array}$ \\
\hline 5 & Uji luas & Diisi & Diisi karakter \\
\hline
\end{tabular}

\begin{tabular}{|c|c|c|c|}
\hline No & Test Uji & Valid Data & Invalid Data \\
\hline & $\begin{array}{l}\text { tanah } \\
\text { bangunan }\end{array}$ & $\begin{array}{l}\text { karakter } \\
\text { numerik }\end{array}$ & $\begin{array}{l}\text { bukan } \\
\text { numerik atau } \\
\text { gabungan } \\
\text { karakter } \\
\text { numerik dan } \\
\text { bukan } \\
\text { numerik }\end{array}$ \\
\hline 6 & $\begin{array}{l}\text { Uji luas } \\
\text { tanah } \\
\text { sarana }\end{array}$ & $\begin{array}{l}\text { Diisi } \\
\text { karakter } \\
\text { numerik }\end{array}$ & $\begin{array}{l}\text { Diisi karakter } \\
\text { bukan } \\
\text { numerik atau } \\
\text { gabungan } \\
\text { karakter } \\
\text { numerik dan } \\
\text { bukan } \\
\text { numerik }\end{array}$ \\
\hline 7 & $\begin{array}{l}\text { Uji luas } \\
\text { tanah } \\
\text { kosong }\end{array}$ & $\begin{array}{l}\text { Diisi } \\
\text { karakter } \\
\text { numerik }\end{array}$ & $\begin{array}{l}\text { Diisi karakter } \\
\text { bukan } \\
\text { numerik atau } \\
\text { gabungan } \\
\text { karakter } \\
\text { numerik dan } \\
\text { bukan } \\
\text { numerik }\end{array}$ \\
\hline 8 & $\begin{array}{l}\text { Uji kode } \\
\text { lokasi } \\
\text { barang }\end{array}$ & $\begin{array}{l}\text { Memilih } \\
\text { kode aset } \\
\text { berdasarkan } \\
\text { pilihan }\end{array}$ & $\begin{array}{l}\text { tidak memilih } \\
\text { kode aset }\end{array}$ \\
\hline 9 & $\begin{array}{l}\text { Uji Tanggal } \\
\text { dokumen }\end{array}$ & $\begin{array}{l}\text { Diisi sesuai } \\
\text { format } \\
\text { tanggal }\end{array}$ & $\begin{array}{l}\text { Diisi tidak } \\
\text { sesuai dengan } \\
\text { format } \\
\text { tanggal }\end{array}$ \\
\hline 10 & $\begin{array}{l}\text { Uji nilai } \\
\text { peroleh }\end{array}$ & $\begin{array}{l}\text { Diisi } \\
\text { karakter } \\
\text { numerik }\end{array}$ & $\begin{array}{l}\text { Diisi karakter } \\
\text { bukan } \\
\text { numerik atau } \\
\text { gabungan } \\
\text { karakter } \\
\text { numerik dan } \\
\text { bukan } \\
\text { numerik }\end{array}$ \\
\hline II & $\begin{array}{l}\text { Uji nilai } \\
\text { buku }\end{array}$ & $\begin{array}{l}\text { Diisi } \\
\text { karakter } \\
\text { numerik }\end{array}$ & $\begin{array}{l}\text { Diisi karakter } \\
\text { bukan } \\
\text { 58umeric } \\
\text { atau gabungan } \\
\text { karakter } \\
\text { 58umeric dan }\end{array}$ \\
\hline
\end{tabular}




\begin{tabular}{clll}
\hline No & Test Uji & Valid Data & Invalid Data \\
\hline & & & $\begin{array}{l}\text { bukan } \\
\text { Numeric }\end{array}$ \\
\hline 12 & $\begin{array}{l}\text { Uji foto } \\
\text { tanah }\end{array}$ & $\begin{array}{l}\text { Melampirkan } \\
\text { foto tanah }\end{array}$ & $\begin{array}{l}\text { Tidak } \\
\text { melampirkan } \\
\text { foto tanah }\end{array}$ \\
\hline
\end{tabular}

Tabel 2. Desain Butir Uji Input Data Gedung dan Bangunan

\begin{tabular}{|c|c|c|c|}
\hline No & Test Uji & Valid Data & $\begin{array}{c}\text { Invalid } \\
\text { Data }\end{array}$ \\
\hline$I$ & $\begin{array}{l}\text { Uji } \\
\text { Formulir } \\
\text { input data } \\
\text { gedung } \\
\text { dan } \\
\text { bangunan }\end{array}$ & $\begin{array}{l}\text { Formulir } \\
\text { input data } \\
\text { gedung dan } \\
\text { bangunan } \\
\text { diisi secara } \\
\text { lengkap }\end{array}$ & $\begin{array}{l}\text { Formulir } \\
\text { input data } \\
\text { gedung dan } \\
\text { bangunan } \\
\text { dikosongkan } \\
\text { atau diisi } \\
\text { sebagian }\end{array}$ \\
\hline 2 & $\begin{array}{l}\text { Uji kode } \\
\text { aset } \\
\text { gedung } \\
\text { dan } \\
\text { bangunan }\end{array}$ & $\begin{array}{l}\text { Memilih } \\
\text { kode aset } \\
\text { berdasarkan } \\
\text { pilihan }\end{array}$ & $\begin{array}{l}\text { tidak } \\
\text { memilih } \\
\text { kode aset }\end{array}$ \\
\hline 3 & $\begin{array}{l}\text { Uji } \\
\text { nomor } \\
\text { urut aset } \\
\text { gedung } \\
\text { dan } \\
\text { bangunan }\end{array}$ & $\begin{array}{l}\text { Diisi } \\
\text { karakter } \\
\text { numerik }\end{array}$ & $\begin{array}{l}\text { Diisi } \\
\text { karakter } \\
\text { bukan } \\
\text { numerik atau } \\
\text { gabungan } \\
\text { karakter } \\
\text { numerik dan } \\
\text { bukan } \\
\text { numerik }\end{array}$ \\
\hline 4 & $\begin{array}{l}\text { Uji luas } \\
\text { bangun }\end{array}$ & $\begin{array}{l}\text { Diisi } \\
\text { karakter } \\
\text { numerik }\end{array}$ & $\begin{array}{l}\text { Diisi } \\
\text { karakter } \\
\text { bukan } \\
\text { numerik atau } \\
\text { gabungan } \\
\text { karakter } \\
\text { numerik dan } \\
\text { bukan } \\
\text { numerik }\end{array}$ \\
\hline 5 & Uji lantai & $\begin{array}{l}\text { Diisi } \\
\text { karakter } \\
\text { numerik }\end{array}$ & $\begin{array}{l}\text { Diisi } \\
\text { karakter } \\
\text { bukan } \\
\text { numerik atau } \\
\text { gabungan }\end{array}$ \\
\hline
\end{tabular}

\begin{tabular}{|c|c|c|c|}
\hline No & Test Uji & Valid Data & $\begin{array}{c}\text { Invalid } \\
\text { Data }\end{array}$ \\
\hline & & & $\begin{array}{l}\text { karakter } \\
\text { numerik dan } \\
\text { bukan } \\
\text { numerik }\end{array}$ \\
\hline 6 & $\begin{array}{l}\text { Uji tahun } \\
\text { selesai }\end{array}$ & $\begin{array}{l}\text { Diisi } \\
\text { karakter } \\
\text { numerik } \\
\text { dengan } \\
\text { panjang } \\
\text { karakter } 4\end{array}$ & $\begin{array}{l}\text { Diisi } \\
\text { karakter } \\
\text { bukan } \\
\text { numerik atau } \\
\text { gabungan } \\
\text { karakter } \\
\text { numerik dan } \\
\text { bukan } \\
\text { numerik } \\
\text { dengan } \\
\text { karakter } \\
\text { kurang dari } 4 \\
\text { dan lebih } \\
\text { dari } 4\end{array}$ \\
\hline 7 & $\begin{array}{l}\text { Uji kode } \\
\text { ruang }\end{array}$ & $\begin{array}{l}\text { Memilih } \\
\text { kode ruang } \\
\text { gedung }\end{array}$ & $\begin{array}{l}\text { tidak } \\
\text { memilih } \\
\text { kode ruang } \\
\text { gedung }\end{array}$ \\
\hline 8 & $\begin{array}{l}\text { Uji } \\
\text { Tanggal } \\
\text { imb }\end{array}$ & $\begin{array}{l}\text { Diisi sesuai } \\
\text { format } \\
\text { tanggal }\end{array}$ & $\begin{array}{l}\text { Diisi tidak } \\
\text { sesuai } \\
\text { dengan } \\
\text { format } \\
\text { tanggal }\end{array}$ \\
\hline 9 & $\begin{array}{l}\text { Uji foto } \\
\text { Gedung } \\
\text { dan } \\
\text { Bagunan }\end{array}$ & $\begin{array}{l}\text { Melampirkan } \\
\text { foto gedung } \\
\text { dan } \\
\text { bangunan }\end{array}$ & $\begin{array}{l}\text { Tidak } \\
\text { melampirkan } \\
\text { foto gedung } \\
\text { dan bagunan }\end{array}$ \\
\hline No & $\frac{\text { 3. Desain B }}{\text { Test Uji }}$ & $\frac{\text { tir Uji Input Da }}{\text { Valid Data }}$ & $\begin{array}{c}\text { Kendaraan } \\
\begin{array}{c}\text { Invalid } \\
\text { Data }\end{array}\end{array}$ \\
\hline I & $\begin{array}{l}\text { Uji } \\
\text { Formulir } \\
\text { input data } \\
\text { kendaraan }\end{array}$ & $\begin{array}{l}\text { Formulir } \\
\text { input data } \\
\text { kendaraan } \\
\text { diisi secara } \\
\text { lengkap }\end{array}$ & $\begin{array}{l}\text { Formulir } \\
\text { input data } \\
\text { kendaraan } \\
\text { dikosongkan } \\
\text { atau diisi } \\
\text { sebagian }\end{array}$ \\
\hline 2 & $\begin{array}{l}\text { Uji kode } \\
\text { aset } \\
\text { kendaraan }\end{array}$ & $\begin{array}{l}\text { Memilih } \\
\text { kode aset } \\
\text { berdasarkan }\end{array}$ & $\begin{array}{l}\text { tidak } \\
\text { memilih } \\
\text { kode aset }\end{array}$ \\
\hline
\end{tabular}




$$
\begin{array}{r|l}
\text { Jurnal Sains Komputer dan Teknologi Informasi } & \text { Page } \\
\text { e - issn : 2655-7460. Volume 3 No.2, Mei 2021 } & 56-63
\end{array}
$$

\begin{tabular}{|c|c|c|c|}
\hline No & Test Uji & Valid Data & $\begin{array}{c}\text { Invalid } \\
\text { Data }\end{array}$ \\
\hline \multicolumn{4}{|c|}{ pilihan } \\
\hline 3 & $\begin{array}{l}\text { Uji nomor } \\
\text { urut aset } \\
\text { kendaraan }\end{array}$ & $\begin{array}{l}\text { Diisi } \\
\text { karakter } \\
\text { numerik }\end{array}$ & $\begin{array}{l}\text { Diisi } \\
\text { karakter } \\
\text { bukan } \\
\text { numerik } \\
\text { atau } \\
\text { gabungan } \\
\text { karakter } \\
\text { numerik dan } \\
\text { bukan } \\
\text { numerik }\end{array}$ \\
\hline 4 & $\begin{array}{l}\text { Uji tahun } \\
\text { kendaraan }\end{array}$ & $\begin{array}{l}\text { Diisi } \\
\text { karakter } \\
\text { numerik } \\
\text { dengan } \\
\text { panjang } \\
\text { karakter } 4\end{array}$ & $\begin{array}{l}\text { Diisi } \\
\text { karakter } \\
\text { bukan } \\
\text { numerik } \\
\text { atau } \\
\text { gabungan } \\
\text { karakter } \\
\text { numerik dan } \\
\text { bukan } \\
\text { numeric } \\
\text { dengan } \\
\text { karakter } \\
\text { kurang dari } \\
4 \text { dan lebih } \\
\text { dari } 4\end{array}$ \\
\hline 5 & $\begin{array}{l}\text { Uji daya } \\
\text { muatan }\end{array}$ & $\begin{array}{l}\text { Diisi } \\
\text { karakter } \\
\text { numerik }\end{array}$ & $\begin{array}{l}\text { Diisi } \\
\text { karakter } \\
\text { bukan } \\
\text { numerik } \\
\text { atau } \\
\text { gabungan } \\
\text { karakter } \\
\text { numerik dan } \\
\text { bukan } \\
\text { numerik }\end{array}$ \\
\hline 6 & $\begin{array}{l}\text { Uji cc } \\
\text { mesin }\end{array}$ & $\begin{array}{l}\text { Diisi } \\
\text { karakter } \\
\text { numerik }\end{array}$ & $\begin{array}{l}\text { Diisi } \\
\text { karakter } \\
\text { bukan } \\
\text { numerik } \\
\text { atau } \\
\text { gabungan } \\
\text { karakter } \\
\text { numerik dan } \\
\text { bukan }\end{array}$ \\
\hline
\end{tabular}

\begin{tabular}{|c|c|c|c|}
\hline No & Test Uji & Valid Data & $\begin{array}{c}\text { Invalid } \\
\text { Data }\end{array}$ \\
\hline & & & numerik \\
\hline 7 & Uji harga & $\begin{array}{l}\text { Diisi } \\
\text { karakter } \\
\text { numerik }\end{array}$ & $\begin{array}{l}\text { Diisi } \\
\text { karakter } \\
\text { bukan } \\
\text { numerik } \\
\text { atau } \\
\text { gabungan } \\
\text { karakter } \\
\text { numerik dan } \\
\text { bukan } \\
\text { numerik }\end{array}$ \\
\hline 8 & $\begin{array}{l}\text { Uji nilai } \\
\text { buku }\end{array}$ & $\begin{array}{l}\text { Diisi } \\
\text { karakter } \\
\text { numerik }\end{array}$ & $\begin{array}{l}\text { Diisi } \\
\text { karakter } \\
\text { bukan } \\
\text { numerik } \\
\text { atau } \\
\text { gabungan } \\
\text { karakter } \\
\text { numerik dan } \\
\text { bukan } \\
\text { numerik }\end{array}$ \\
\hline 9 & $\begin{array}{l}\text { Uji kode } \\
\text { lokasi } \\
\text { barang }\end{array}$ & $\begin{array}{l}\text { Memilih } \\
\text { kode lokasi } \\
\text { aset } \\
\text { berdasarkan } \\
\text { pilihan }\end{array}$ & $\begin{array}{l}\text { tidak } \\
\text { memilih } \\
\text { kode lokasi } \\
\text { aset }\end{array}$ \\
\hline 10 & $\begin{array}{l}\text { Uji foto } \\
\text { kendaraan }\end{array}$ & $\begin{array}{l}\text { Melampirkan } \\
\text { foto } \\
\text { kendaraan }\end{array}$ & $\begin{array}{l}\text { Tidak } \\
\text { melampirkan } \\
\text { foto } \\
\text { kendaraan }\end{array}$ \\
\hline
\end{tabular}

\begin{tabular}{|c|c|c|c|}
\hline \multicolumn{4}{|c|}{ Lainnya } \\
\hline No & Test Uji & Valid Data & $\begin{array}{c}\text { Invalid } \\
\text { Data }\end{array}$ \\
\hline I & $\begin{array}{l}\text { Uji } \\
\text { Formulir } \\
\text { input data } \\
\text { aset tetap } \\
\text { lainnya }\end{array}$ & $\begin{array}{l}\text { Formulir } \\
\text { input data } \\
\text { aset tetap } \\
\text { lainnya diisi } \\
\text { secara } \\
\text { lengkap }\end{array}$ & $\begin{array}{l}\text { Formulir } \\
\text { input data } \\
\text { aset tetap } \\
\text { lainnya } \\
\text { dikosongkan } \\
\text { atau diisi } \\
\text { sebagian }\end{array}$ \\
\hline 2 & $\begin{array}{l}\text { Uji kode } \\
\text { aset tetap } \\
\text { lainnya }\end{array}$ & $\begin{array}{l}\text { Memilih } \\
\text { kode aset } \\
\text { berdasarkan }\end{array}$ & $\begin{array}{l}\text { tidak } \\
\text { memilih } \\
\text { kode aset }\end{array}$ \\
\hline
\end{tabular}

Tabel 4. Desain Butir Uji Input Data Aset Tetap 


\begin{tabular}{|c|c|c|c|}
\hline No & Test Uji & Valid Data & $\begin{array}{c}\text { Invalid } \\
\text { Data }\end{array}$ \\
\hline & & pilihan & \\
\hline 3 & $\begin{array}{l}\text { Uji banyak } \\
\text { barang }\end{array}$ & $\begin{array}{l}\text { Diisi } \\
\text { karakter } \\
\text { numerik }\end{array}$ & $\begin{array}{l}\text { Diisi } \\
\text { karakter } \\
\text { bukan } \\
\text { numerik atau } \\
\text { gabungan } \\
\text { karakter } \\
\text { numerik dan } \\
\text { bukan } \\
\text { numerik }\end{array}$ \\
\hline 4 & $\begin{array}{l}\text { Uji } \\
\text { tercatat } \\
\text { dalam }\end{array}$ & $\begin{array}{l}\text { Memilih dari } \\
\text { dua pillihan } \\
\text { pencatatan }\end{array}$ & $\begin{array}{l}\text { Tidak } \\
\text { memilih } \\
\text { pillihan } \\
\text { penatatan }\end{array}$ \\
\hline 5 & $\begin{array}{l}\text { Uji nilai } \\
\text { perolehan } \\
\text { barang }\end{array}$ & $\begin{array}{l}\text { Diisi } \\
\text { karakter } \\
\text { numerik }\end{array}$ & $\begin{array}{l}\text { Diisi } \\
\text { karakter } \\
\text { bukan } \\
\text { numerik atau } \\
\text { gabungan } \\
\text { karakter } \\
\text { numerik dan } \\
\text { bukan } \\
\text { numerik }\end{array}$ \\
\hline 6 & $\begin{array}{l}\text { Uji lokasi } \\
\text { barang }\end{array}$ & $\begin{array}{l}\text { Memilih } \\
\text { kode lokasi } \\
\text { aset } \\
\text { berdasarkan } \\
\text { pilihan }\end{array}$ & $\begin{array}{l}\text { tidak } \\
\text { memilih } \\
\text { kode lokasi } \\
\text { aset }\end{array}$ \\
\hline 7 & $\begin{array}{l}\text { Uji foto } \\
\text { aset tetap } \\
\text { lainnya }\end{array}$ & $\begin{array}{l}\text { Melampirkan } \\
\text { foto aset } \\
\text { tetap lainnya }\end{array}$ & $\begin{array}{l}\text { Tidak } \\
\text { melampirkan } \\
\text { foto aset } \\
\text { tetap lainnya }\end{array}$ \\
\hline
\end{tabular}

\section{IMPLEMENTASI DAN PEMBAHASAN}

Implementasi metode equivalence partitioning didasarkan pada premis masukan dan keluaran dari suatu komponen yang dipartisi ke dalam kelas - kelas, menurut spesifikasi dari komponen tersebut, yang akan diperlakukan sama (ekuivalen) oleh komponen tersebut.

Berdasarkan rencana desain butir uji yang telah dibuat sebelumnya, masing-masing tes uji dimasukkan kedalam kelas-kelas uji yang dibuat untuk memastikan rencana pengujian sesuai dengan yang direncanakan.

\section{I. Implementasi Butir Uji Input Data Tanah}

Masing-masing test uji pada butir uji input data tanah dibuatkan beberapa kelas uji sesuai dengan desain uji validitas dan invaliditas, yang terdiri dari : (I) Kelas uji formulir input data tanah; (2) Kelas uji kode aset tanah; (3) Kelas uji nomor urut aset tanah; (4) Kelas uji luas tanah; (5) Kelas uji luas tanah bangunan; (6) Kelas uji luas tanah sarana; (7) Kelas uji luas tanah kosong; (8) Kelas uji kode lokasi barang; (9) Kelas uji tanggal dokumen; (I0) Kelas uji nilai peroleh; (II) Kelas uji nilai buku; (I2) Kelas uji foto tanah.

\subsection{Implementasi Butir Uji Input Data Gedung dan Bangunan}

Masing-masing test uji pada butir uji input data gedung dan bangunan dibuatkan beberapa kelas uji sesuai dengan desain uji validitas dan invaliditas yang terdiri dari : (I) Kelas $\mathrm{Uji}_{\mathrm{ji}}$ Formulir Input Data Gedung Dan Bangunan; (2) Kelas Uji Kode Aset Gedung Dan Bangunan; (3) Kelas Uji Nomor Urut Aset Gedung Dan Bangunan; (4) Kelas Uji Luas Bangun; (5) Kelas Uji Lantai; (6) Kelas Uji Tahun Selesai; (7) Kelas Uji Kode Ruang; (8) Kelas Uji Tanggal IMB; (9) Kelas Uji Foto Gedung dan Bangunan.

\subsection{Implementasi Butir Uji Input Data Kendaran \\ Masing-masing test uji pada butir uji input} data kendaraan dibuatkan beberapa kelas uji sesuai dengan desain uji validitas dan invaliditas yang terdiri dari : (I) Kelas Uji Formulir Input Data Kendaraan; (2) Kelas Uji Kode Aset Kendaraan; (3) Kelas Uji Nomor Urut Aset Kendaraan; (4) Kelas Uji Tahun Kendaraan; (5) Kelas Uji Daya Muatan; (6) Kelas Uji CC Mesin; (7) Kelas Uji Harga; (8) Kelas Uji Nilai Buku; (9) Kelas Uji Kode Lokasi Barang; (10) Kelas Uji Foto Kendaraan. 


\subsection{Implementasi Butir Uji Input Data} Aset Tetap Lainnya

Masing-masing test uji pada butir uji input data aset lainnya dibuatkan beberapa kelas uji sesuai dengan desain uji validitas dan invaliditas yang terdiri dari : (I) Kelas Uji Formulir Input Data Aset Tetap Lainnya; (2) Kelas Uji Kode Aset Tetap Lainnya; (3) Kelas Uji Banyak Barang; (4) Kelas Uji Tercatat Dalam; (5) Kelas Uji Nilai Perolehan Barang; (6) Kelas Uji Lokasi Barang; (7) Kelas Uji Foto Aset Tetap Lainnya.

\subsection{Pembahasan Analisis Hasil Pengujian}

Setelah proses pengujian dilakukan sesuai dengan kondisi valid dan tidak valid serta hasil yang dirapkan setelah hasil pengujian, didapatkan hasil seperti yang tampak pada tabel berikut :

Tabel 5. Analisis Hasil

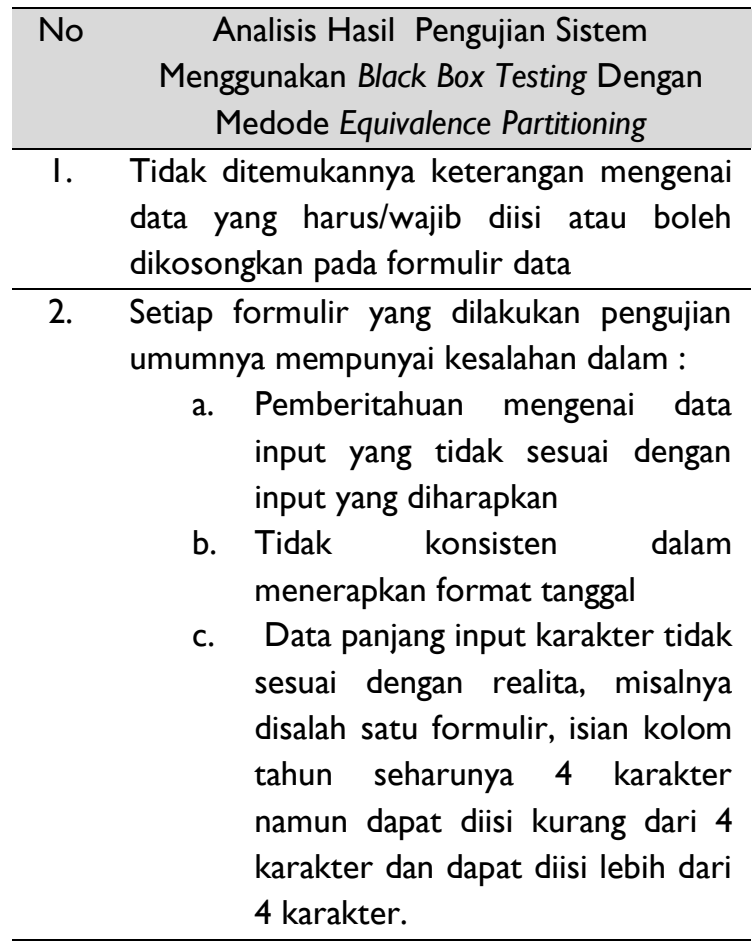

3. Analisis desain sistem kurang terlihat, khususnya pembuatan dan pegembangan desain basis data yang dapat dikatakan tidak sesuai dengan data masukkan yang diharapkan.

\begin{tabular}{ll}
\hline 4 Sistem masih terdapat banyak bug \\
alogritma yang perlu dibenai untuk \\
menghasilkan sistem yang baik.
\end{tabular}

5.6. Analisis Solusi Praktis
Beberapa acuan solusi yang dapat direkomendasikan tampak seperti pada tabel berikut ini :

Tabel 6. Analisis Solusi Praktis

\begin{tabular}{c} 
No Analisis Solusi Praktis Terhadap Sistem \\
\hline I. Dilakuakan kembali rekayasa perangkat \\
lunak, dengan memperhatikan : \\
a. Proses desain requirement \\
b. Desain sistem yang meliputi \\
desain basis data, desain input, \\
desain proses serta desain output. \\
c. Proses algortima pengkodean \\
disesuaikan dengan fungsionalitas \\
dari setiap proses sistem yang \\
telah didesain sebelumnya.
\end{tabular}

2. Lakukan testing dan debugging yang intens agar mendapatkan gambaran celah kesalahan sistem agar dapat segera diperbaiki sebelum sistem tersebut digunakan.

\section{KESIMPULAN DAN SARAN}

\section{I. Kesimpulan}

I. Dari hasil pengujian Black-Box Testing dengan metode Equivalence Partitioning, masih banyak terdapat kesalahan-kesalahan algoritma dalam proses input data.

2. Struktur basis data dibuat tidak disesuaikan dengan karakteristik sistem yang akan dibuat.

3. Masih banyak terdapat bug pada sistem yang dapat dikatakan sistem belum layak untuk digunakan.

\subsection{Saran}

Perlu dilakukan proses rekayasa perangkat lunak ulang mulai yang dimulai dari proses requirement, design, implementation hingga proses testing dan debugging.

\section{DAFTAR PUSTAKA}

Bhat, A, and Quadri, S.M.K, 2015, Equivalence Class Partitioning and Boundary Value Analysis $=\mathrm{A}$ review, 2nd International Conference on Computing for Sustainable Global Development (INDIACom). 
Kamus Besar Bahasa Indonesia, 2018, Arti Kata Analisis, http://kbbi.kata.web.id/analisis/, Tanggal akses 24 Februari 2018 Pukul 14.00 WIB.

Prediksi Kelulusan SNMPTN), Jurnal Ilmiah Teknologi Informasi Terapan (JITTER) Volume I, No 3, 10 Agustus 2015 p : 31-16.

Norhayati and Rosmiati. 2019. Implementasi Media Pembelajaran Berbasis Multimedia Untuk Meningkatkan Minat dan Motivasi Belajar Bahasa Inggris pada Anak Di Desa Petuk Ketimpun Provinsi Kalimantan Tengah. Jurnal Sains Komputer dan Teknologi Informasi. Vol I Issue 2 e-ISSN 2655-7460. https://doi.org//0.33084/jsakti.v li2.872.

Nugroho, Adi. 2010. Rekayasa Perangkat Lunak Berorientasi Objek dengan Metode USDP. ANDI OFFSET. Yogyakarta.

Rahman, Fazri, 2016, Sistem Informasi Inventarisasi Barang Berbasis Web Pada Madrasah Tsanawiyah Negeri 2 Palangka Raya, STMIK Palangkaraya, Palangka Raya.

Sam'ani. Annisa, S., Heri., 2018. Rancang Bangun Aplikasi Pengawasan Dan Pengendalian Komputer Laboratorium Multimedia STMIK Palangkaraya. Jurnal Sains Komputer dan Teknologi Informasi. Vol I Issue I e-ISSN 2655-7460.

https://doi.org/ / 0.33084/jsakti.vlil.548

Sam'ani, Qamaruzzaman, M. H, 2019. Rancang Bangun Visualisasi Pembelajaran Berbasis Android Untuk Anak. Jurnal SISTEMASI. Vol 8 No 3 e-ISSN 2540-97I9. https://doi.org/10.32520/stmsi.v8i3.518

Sam'ani, Sutami and Qamaruzzaman, M. H. (2019). Implementasi Aplikasi Pembelajaran Untuk Anak Berbasis Android. Martabe : Jurnal Pengabdian Kepada Masyarakat, Vol 2 No 2, p. 106. doi: 10.31604/jpm.v2i2. 106-II0.

Shi, Mingtao, 2010, Software Functional Testing from the Perspective of Business Practice Computer and Information Science, www.ccssenet.org/cis.

Wibisono, Waskitho dan Fajar Baskoro, 2002, Pengujian Perangkat Lunak Dengan Menggunakan Behavior UML, Jurnal IImiah
Mustaqbal, M. Sidi, Roeri Fajri Firdaus, dan Hendra Rahmadi, 2015, Pengujian Aplikasi Menggunakan Black Box Testing Boundary Value Analysis (Studi Kasus : Aplikasi Teknologi Informasi (JUTI) Volume I, Nomor I, Juli 2002, p : 43-50. 